\title{
A HOUSE DIVIDED: DONALD TRUMP AND THE TRANSFORMATION OF AMERICAN POLITICS
}

\author{
Sebastião C. Velasco e Cruz ${ }^{1}$
}

Taking as its methodological principle the requirement to articulate long-term trends and conjunctural determinants as key to the analysis of political change, this article reviews the literature on political polarization in American society and reconstructs the ascension process of the conservative movement, as essential elements for the interpretation of the Trump phenomenon. It shows, however, that the latter is only understandable by integrating into the analysis the impact of the 2008 financial crisis, the election of Barack Obama - the first black president in US history - and the consequent outbreak of the Tea Party, a reactionary movement that had a strong destabilizing effect on the Republican Party, paving the way for the New York tycoon's overwhelming rush.

Keywords: Donald Trump; polarization; Republican Party; conservative movement.

\section{UMA CASA DIVIDIDA: DONALD TRUMP E A TRANSFORMAÇÃO DA POLÍTICA AMERICANA}

Tomando a exigência de articular tendências de longo prazo e determinantes conjunturais como princípio de método-chave para a análise da mudança política, este artigo passa em revista a literatura sobre a polarização política na sociedade americana e reconstitui o processo de ascensão do movimento conservador, como elementos essenciais à interpretação do fenômeno Trump. Mostra, entretanto, que o mesmo só se torna compreensível ao se integrar na análise o impacto da crise financeira de 2008, a eleição de Barack Obama - primeiro presidente negro na história dos Estados Unidos - e a consequente eclosão do Tea Party, movimento reacionário que teve forte efeito desestabilizador sobre o Partido Republicano, abrindo o caminho nele para a arrancada avassaladora do magnata nova-iorquino.

Palavras-chave: Donald Trump; polarização; Partido Republicano; movimento conservador.

\section{UNA CASA DIVIDIDA: DONALD TRUMP Y LA TRANSFORMACIÓN DE LA POLÍTICA ESTADOUNIDENSE}

Admitiendo la exigencia de articular las tendencias de largo plazo y las determinantes coyunturales como principio de método clave para el análisis del cambio político, este artículo examina la literatura sobre polarización política en la sociedad estadounidense y reconstituye el proceso del ascenso del movimiento conservador, como elementos esenciales para la interpretación del fenómeno Trump. Sin embargo, se demuestra que dicho fenómeno solo se puede comprender si además se analiza el impacto de la crisis financiera de 2008, la elección de Barack Obama - el primer presidente negro en la historia de Estados Unidos - y la consecuente eclosión del Tea

\footnotetext{
1. Professor titular do Departamento de Ciência Política da Universidade Estadual de Campinas (Unicamp) e do Programa de Pós-Graduação em Relações Internacionais San Tiago Dantas (Universidade Estadual Paulista - Unesp/Unicamp/Pontifícia Universidade Católica de São Paulo - PUC-SP); e vice-coordenador e pesquisador do Instituto Nacional de Ciência e Tecnologia para Estudos sobre os Estados Unidos (INCT-INEU).
} 
Party, un movimiento reaccionario que produjo un fuerte efecto desestabilizador sobre el Partido Republicano, abriendo el camino para la arrancada avasalladora del magnate neoyorkino.

Palabras clave: Donald Trump; polarización; Partido Republicano; movimiento conservador. JEL: 051; N42.

\section{THE TRUMP PHENOMENON AND A HOUSE DIVIDED}

As he enters his third year in office, Donald Trump keeps on shocking the world with his attitudes, which not only raise tensions in the American political system, but also spread disquietude across the world.

Just recently he announced he was going to decree a national state of emergency in order to build a wall touted to his voters as a panacea for stopping illegal immigration from Mexico. Weeks before, he had negotiated with the House Democratic majority leader to ensure the functioning of public services that had been compromised by his own refusal to sign the 2019 budget if Congress failed to appropriate funding for the wall. Yet the deal would not bring an end to the conflict. At the time, Trump warned that he would resort to exceptional means to prevail. Soon all would see he was not bluffing.

Scandal has been a constant in Trump's behavior from the very moment he announced his decision to run for the presidency as the Republican Party's candidate. And it is in astonishment that observers - in the United States and elsewhere - verify that, from one scandal to another, he has reaped impressive results, such as defeating some of the most prominent figures of a party he had had no history in; or reaching the Presidency without changing a word of his transgressive speech and insolent attitudes; and extending such traits to his government actions, without ever backing down in face of the virulent - internal and external - criticism they aroused.

Brief as they are, the references made above raise a difficult question: How can we make sense of Donald Trump's successful bet on a strategy that, at first sight, seemed senseless? Over and beyond the personal traits and ruses of the media celebrity and entrepreneur, how has such an unusual political phenomenon been made possible?

The aim of this article is not to provide a definitive answer to questions like these, which will long remain a challenge for the analytical capacity of political scientists and historians. Here the goal is just to draw the general lines of an interpretive argument whose point of departure is the candid idea that Trump is at the same time a symptom of the American political society crisis and a key factor in its worsening. 
"A house divided". Taken from the Bible, the metaphor that opens the title of this article alludes to one of Abraham Lincoln's most celebrated speeches, and because of that has become common place in American political literature. I do not recover it for the sake of mimesis or even to suggest a forceful analogy between two quite discrepant historical periods. The reference seems useful because it allows me to parsimoniously introduce a methodological point of view.

I ask the reader to consider this passage of the statesman's address.

"A house divided against itself cannot stand". (...) I believe this government cannot endure, permanently half slave and half free. I do not expect the Union to be dissolved - I do not expect the house to fall - but I do expect it will cease to be divided. It will become all one thing or all the other. ${ }^{2}$

What is striking in this excerpt is the fact that Lincoln aims his speech at what he viewed as the unacceptable persistence of a state of schism that was a constituent element of American society and had lasted by then nearly eighty years. Indeed, in its first decades the American Republic had accommodated with relative ease the structural heterogeneity between, on one hand, a North founded on smallholdings and free labor, and on the other, a South based on large plantations and slavery - to such an extent that the labor regime barely made it onto the agenda. The political life of the young country was the stage of several, often intense, conflicts, yet the issues that divided opinions had to do with broad conceptions regarding the good order - distribution of power between the states and the federation; more or less space for popular participation; the role of the State in the economy - and interests of local economic sectors, such as tariffs. What "divides the house" is not the social heterogeneity per se but the political treatment it is afforded.

Lincoln was fully aware of that and made it clear in the sentence that precedes the excerpt above.

We are now far into the fifth year, since a policy was initiated, with the avowed object, and confident promise, of putting an end to slavery agitation. Under the operation of that policy, that agitation has not only, not ceased, but has constantly augmented. In my opinion, it will not cease, until a crisis shall have been reached, and passed. ${ }^{3}$

And then he introduces the thought expressed in the famous sentence: "A house divided against itself cannot stand". ${ }^{4}$

2. Available in: <http://www.abrahamlincolnonline.org/lincoln/speeches/house.htm>.

3. Available in: <http://www.abrahamlincolnonline.org/lincoln/speeches/house.htm>.

4. Available in: <http://www.abrahamlincolnonline.org/lincoln/speeches/house.htm>. 
That is the point I wish to highlight. For many years coexistence between North and South was possible by force of a political compromise that established rules for a mutually acceptable relationship (Missouri Compromise, 1820). When the compromise failed, crisis ensued.

My interest in the celebrated passage is the combination of structural conditions, long-term trends, and time-bound determinations that steadily drive tension in a society and ultimately, lead it to a breaking point.

It is precisely the quest for this type of connection that will guide this analytical exercise on the "Trump phenomenon."

\section{MISMATCHES: THE POLITICAL POLARIZATION DEBATE IN THE UNITED STATES}

\subsection{Severed relations}

I shall start with the background: The shaping of political and ideological conflict in the United States in the period that precedes the election of Donald Trump.

This configuration is described by a qualified observer as:

the central obstacle to more effective action against our most pressing problems is an unrelenting polarization of American politics that has divided Washington and the country into hostile, even irreconcilable camps. (...) For most of the past two decades the two sides have collided with such persistent and unwavering disagreement on everything from taxes to Social Security to social and foreign policy that it sometimes seems they are organizing not only against each other, but against the idea of compromise itself (Brownstein, 2008, p. 11).

The author of these lines is a journalist, and not all of those studying the subject would endorse the alarming tone of his appraisal. Still, some of the elements it contains form a consensus.

In effect, analysis of roll call votes in the House and the Senate - the data available encompasses the complete history of both chambers - shows that inter-partisan agreement has reached historical lows. Democrats and Republicans tend to place themselves in opposite camps in a growing number of key votes and, increasingly, to vote in bloc. This behavior, more likely to be expected in the House, manifests itself in the Senate too, where indiscipline is rare. Senators tend to obey the orientation of the Grand Old Party (GOP) leadership, while bipartisan concurrence has also become rarer.

This pattern becomes crystal clear in the level of partisan unity, a measure of how united representatives and senators of each party vote along party lines as surveyed by a prestigious nonpartisan publication for more than half a century, showing unity ranging between $66 \%$ and $70 \%$ in both chambers during the 
Eisenhower presidency and between $85 \%$ and $90 \%$ during the George W. Bush administration (Brownstein, 2008, p. 13). ${ }^{5}$

That is not all. Many researchers seek to characterize the ideological profile of Congress members, which in the American case means situating them along a continuum opposing, at both ends, conservatives and liberals, an imperfect proxy for the universal classification of right-leaning and left-leaning political/ideological positions. To that effect, they have traditionally used scores given to lawmakers by different interest groups based on their positions in selected votes. Given the limitations of this instrument, as it does not allow for intertemporal comparisons (how can we situate along such a continuum a Democratic politician as Harry Truman and another one, from the same party yet from another generation, as Bill Clinton?), the selection of the votes is determined by the interests of each group and not by objective analytical criteria - specialists have come up with much more sophisticated statistical measures to study the ideological composition of the House of Representatives and the Senate. ${ }^{6}$

I find it unnecessary to delve into these measures, which are all based on analysis of the behavior of lawmakers in roll call votes. For the purposes of the argument outlined here it suffices to transcribe the findings presented by pioneering researchers in this kind of analysis.

1) Almost all political conflict in Congress is expressed in theliberal/conservative terms. (...) Other dimensions, such as a civil rights dimension, have largely vanished, as the coalitions on those issues have increasingly begun to match those of the liberal-conservative dimension.

2) The dispersion of positions of members on the liberal-conservative dimension has increased. Compared to the 1960s, extreme conservative as well as extreme liberal positions are more likely to be represented in Congress.

3) The ideological composition of the two political parties has become more homogeneous. Intra-party regional differences, such as those between northern and southern Democrats, have abated.

4) The positions of the average Democrat and average Republican member of Congress have become more widely separated. That is, the difference in the party means has increased over time.

5) There is less overlap in the positions of the parties. There are no longer any liberal Republicans or conservative Democrats in Congress (McCarty, Poole e Rosenthal, 2006, p. 23).

5. Congressional Quarterly Weekly Reports, January 1, 2007.

6. The assumption guiding these exercises and the statistical tools developed for their application, however, are not free of problems. A substantiated criticism available in: <https://my.vanderbilt.edu/joshclinton/files/2015/10/BCL AJPSInitialSubmit.pdf>. 
This is the core meaning of the term polarization: Cleavage of a given polity in two camps that are split not only in terms of differences in the positions they take on key issues, but also in terms of the size of such differences.

There is broad consensus in the literature that the concept adequately describes the pattern observed in the United States Congress in the last decades. On this common ground, intense controversy has long developed among analysts of American politics. This controversy gravitates around three basic questions: i) How can we characterize the phenomenon? What is its scope? To what extent is the phenomenon restricted to the universe of politicians and activists in both parties? Or has it also spread to the entire electorate?; ii) how can we explain the phenomenon? How to understand the transit to this pattern of political competition, considering that in the not so remote past there was a wide convergence between the Democratic Party and the Republican Party - to such an extent that they came to be regarded by slanderous criticism, not as true parties, but as two of a kind, wings of a single big party?; and iii) how can we assess such change normatively? To what extent is this phenomenon positive or negative for healthy democratic life?

I abstain from commenting the third question because it concerns us only indirectly and, in that regard, our problems, as Brazilians, are much more serious. But we ought to examine the others with some attention.

\subsection{A society divided?}

Let us consider, to begin with, the contrast contained in the data.

After a long period of supremacy that starts with Franklin Delano Roosevelt's victory in 1932, from 1952 onwards the Democratic Party loses its dominant position in presidential elections. In effect, of the eleven presidential elections held between 1952 and 1992, seven were won by the Republicans, four of which - in 1952, 1956, 1972, and 1984 - by a sweeping majority, with Republicans leading by more than ten percentage points in the polls. The four Democratic wins over the period were much harder to get, with only one of them by two figures - that of Lyndon Johnson over Barry Goldwater, in 1964.

In Congress, the relation of forces between the two parties did not change the same way. Buoyed by Reagan's landslide victory in 1984, the Republicans interrupted Democratic hegemony in the Senate, a legislature they were to lead eight times, from 1980 through 2004, against five Democratic Senate majorities. The House of Representatives, however, remained long after that as an impregnable stronghold: Over the period spanning from 1930 to 1992, of the thirty-two elections to the House of Representatives, the Democrats boasted thirty victories (Black and Black, 2007, p. 6; Abramowitz, 2018, p. 20). 
The discrepancy expressed by these figures tells us something important about the behavior of the electorate: During that period, a significant share of the voters split their vote quite naturally, voting for a party to the Presidency and for another party to the House. Yet they exhibited different voting patterns, as pointed out by Alan Abramowitz (2018, p. 32), a most renowned scholar in the field:

when we compare the voting patterns of Democrats and Republicans during this era, we see that Republicans were much more loyal than Democrats in presidential elections while Democrats were somewhat more loyal than Republicans in House elections. On average, 92 percent of Republicans voted for Republican presidential candidates while only 76 percent of Democrats voted for Democratic presidential candidates. But in House elections, Republicans defected more frequently: 81 percent of Democrats voted for Democratic candidates but only 75 percent of Republicans voted for Republican candidates.

Over the following period, electoral behavior would undergo a dramatic change: The race would be nationalized; split voting would practically disappear; and voters would increasingly vote in line with their partisan preferences. The turning point was the 1994 midterm campaign, which gave the Republicans broad control of both houses of Congress. From then on, the pattern stabilizes. According to a survey conducted by the American National Election Studies (ANES), in 2012 straight-ticket voting (voting on candidates of the same party for president and representatives) broke the 87-percent record, reached in 1952, for the House, and with $90 \%$ exceeded by one point the record established in 1960 for the Senate (Abramowitz, 2018, p. 2).

At the same time, there is a remarkable shift in both parties' bases in terms of political preferences and ideological orientations. Until the late 1980s, correspondence between voters self-identified as "conservatives" and the Republican Party and between "liberal" voters and the Democratic Party was quite imperfect. Though, naturally, in unequal proportions, both political parties had many politicians and voters with overlapping profiles (Levendusky, 2009).

Given the known centrality of ethnic and religious identities in American politics, that shift prompted a partisan repositioning of social groups along these traits, as stated by two specialists mentioned earlier in this article:

the old Democratic advantage among White electors, established during the New Deal, ended during the Reagan years. An average Democratic lead of 12 points between 1952 and 1980 (43 percent to 31 percent) gave way to a 6- point Republican edge during the elections from 1984 through 2004 (40 percent to 34 percent). (...) In the 2004 presidential election, 45 percent of white voters were Republicans, while only 31 percent were Democrats (Black and Black, 2007, p. 11). 
This shift was compensated by a change in electorate composition and a Democratic edge in the vote of the minorities. According to exit polls, in 2004 $78 \%$ of the voters were white, $11 \%$ African American, 8\% Latino, and 3\% "new minorities" (mainly Asians). Democrats led among these groups: 52\%-29\%, among Latinos; 40\%-28\%, among Asian voters; and 78\%-8\%, among African Americans (Black and Black, 2007, p. 23).

The change observed in the voting orientation of religious groups is also remarkable. Over the period considered, white Christians move decidedly to the Republican Party, a movement made by Protestants and Catholics alike - which for the latter group meant a major departure from their century-long alignment with the Democratic Party. And the information should come as no surprise to the reader that this process was particularly more significant with respect to the evangelical vote (Black and Black, 2007, p. 20-25).

In the context of a genuine majority-based system such as the American, where the winner takes all, whether the difference between winner and loser is by many points or just by some tenths, and where a President's election is decided in an electoral college, the dual effect of these trends combined is a steady increase in the level of uncertainty surrounding electoral results and, paradoxically, a concentration of the race in a decreasing number of places in the geographic space. Victories decided by a majority at times insignificant, won in a very low proportion of electoral districts, and in an extremely reduced number of states these features have characterized electoral races in the United States recently (Hopkins, 2017).

The facts summarized here have been firmly established. Controversy among specialists concerns only how they should be interpreted. To some, they clearly indicate that the polarization observed in the partisan sphere has spread to the whole of society. Not only politicians and activists, but also donors, interest groups, and ultimately the voters tend to be increasingly sorted by ideological differences. To others, this view is misguided, because in the electorate as a whole moderate opinion would still prevail. The electorate has not polarized; it has sorted, yet mostly remaining little interested in politics and manifesting overwhelmingly "centrist" positions when consulted (Fiorina, Abrams and Pope, 2010). ${ }^{7}$

Polarization or sorting?

I will not join a debate that, from a distance, looks somewhat forceful. We had better move on to the other side of the debate.

7. The best-known representative of this point of view is political scientist Morris Fiorina, who took on the opposing thesis in a best-selling book. Since then, he has had a remarkable presence in this debate, with several articles and books, mostly in partnership with Samuel Abrams. 


\subsection{Polarization: determinants and the obscure realm of affect}

The differences pointed above in characterizing the phenomenon of polarization do not necessarily correspond to those sustained by those participating in the debate of its conditioning factors.

Among the various hypotheses in the literature, some focus on institutional aspects. That is the case of those drawing attention to a change in the House's procedural rules, taking power away from the committees and concentrating it in the hands of lawmakers and the party leadership; and those regarding redistricting and apportionment, strongly benefiting the South and the Interior West for decades. ${ }^{8}$ I include in the same category those arguments emphasizing the growing impact of primary elections on party dynamics.

Others highlight changes underway in different realms, though also strongly impacting political relations: A dizzying increase in social inequality rates, for example, and innovations in the communication technology field, i.e., cable TV and the internet.

There are those still who underscore the long-term effect of dramatic political and judicial decisions - more specifically in the civil and political rights arena and regarding cultural and societal issues.

For reasons of economy, I will consider here only two of these hypotheses.

1) The unanticipated consequences of the rise of primary elections as the method for choosing candidates to elective offices, replacing the traditional selection practice by way of agreements or shows of strength between partisan factions that were subsequently ratified in conventions of arguable representativeness.

Except in the South, where they were used as a tool for excluding blacks and perpetuating the dominant party, primary elections spread all over the United States at the turn of the twentieth century as part of a reform program championed by the progressive movement. Adopted initially, by law, in those states where such movement was stronger, closed (only for voters registered with the party) or open (to independents), in the first half of the last century primary elections became standard procedure for choosing candidates to elective offices in a majority of states (Ansolabehere et al., 2006, p. 74-101).

The raison d'etre of the primaries was the promise of bringing voters closer to their representatives, breaking the monopoly of political machines over partisan life, and getting rid of the shady tools they used to that end: Vote buying; exchange of favors; and procedural manipulation, often leading to acts of violence.

8. I make use here of the classification of political regions adopted by Hopkins (2017, p. 26). 
As time went by, however, they yielded another result. With the declining participation of ordinary voters, these races were dominated by groups of highly motivated activists yet with little representation who imposed on would-be candidates their radicalized agendas, leaving little room for moderate opinions, predominant in the electorate.

That is how the argument goes.

The same rationale also prevailed for presidential nomination bids. The classic procedure, as one can imagine, began with each state's party elites choosing the delegates and ended with leadership agreements that ensured victory to one of the candidates in the national convention. In the context of gradual reform, primaries were introduced in some states and steadily spread to several others. Their result, however, was not binding. The party convention had the last word.

This model started to change dramatically after a tumultuous Democratic convention in Chicago, in 1968. Marked by extreme police violence against young activists who had gathered there in support of a candidate opposing the Vietnam War, the convention elected Hubert Humphrey, the then vice-president of the United States, who had not run in a single primary.

But the Convention also approved the creation of a working group to reexamine the party's nomination procedures. From then on, the Democratic Party introduced a series of rule changes that gave the primaries the decisive role they play today (Fiorina and Abrams, 2011, p. 81).

Through different paths, and with other specificities, the Republican Party acted very much in the same way over the same period.

In both cases, the overall result of the changes was the strengthening of mobilized groups in both parties' bases and the concurrent decline of their leaders' decision-making power.

This line of argument presupposes a triangular relation involving the "median" voter, leaning to one party or the other, yet moderate in opinions and relatively little interested in politically motivated arguments; calculating party leaders; and ideologically oriented activists. Those changes would strengthen the third element, strongly condition the second, and condemn the first to orphanhood; or, with the passing of time, change the average voter's perceptions and way of thinking (Levendusky, 2009).

2) The impact of civil rights and the cultural agenda on the political position of the states of the South.

Since the rebuilding of the party system in the aftermath of the Civil War, with the 1877 compromise that governed the withdrawal of federal troops from 
the South and the institutionalization of racial segregation, expressed in the hypocritical formula separate but equal, the South has organized itself politically for nearly a century as a single-party system under the leadership of groups that control the Southern Black Belt. In the words of Key (1949, p. 5), author of the classic Southern politics, "in its grand outlines the politics of the South revolves around the position of the Negro".

Deeply conservative in social matters, yet not adherents of economic liberalism, southern Democrats were one of the cornerstones of the New Deal coalition, and as such, strongly contributed to Roosevelt's extraordinary electoral success, though also to the defeat of his most advanced proposals (Skocpol and Finegold, 1982).

Despite the tensions, the alliance remained solid throughout Roosevelt's presidency. It was only with Truman that the first cracks in the inter-regional and intraparty deal would start to show. In 1948, not coincidently just one year after the establishment of the United Nations Bill of Human Rights, for the first time the Democratic convention included the desegregation issue in its electoral platform, prompting immediate and strong reactions - the governor of South Carolina, Strom Thurmond, broke ranks with his party that same year and challenged Truman running as a candidate for the ephemeral States' Rights Democratic Party, better known as the Dixiecrats.

This was just the beginning of a cycle that would reach its zenith with the passage of the Civil Rights Act of 1964, and the Voting Rights Act the following year. By then the civil rights movement had mobilized public opinion, and protests against the Vietnam War were beginning to spread in the universities.

Lyndon Johnson is credited with having said, "we have lost the South for a generation", a presage he allegedly made to an aide upon having signed the Civil Rights Act, in 1964. True or apocryphal, the statement describes with precision what was to happen. In 1968 Nixon defeated Democratic candidate Hubert Humphrey, in a tight race in which he was decidedly helped by the dissident candidacy of Alabama's Democratic governor, George Wallace, who obtained more than $13 \%$ of the popular vote with an openly segregationist program. This vote, as expected, was concentrated in the deep South, and gave Wallace the delegates of five states: Arkansas, Louisiana, Mississippi, Alabama, and Georgia.

This was a long and unequal cycle, as we saw when addressing split voting. Yet the presidential elections clearly signaled the direction of change: Except for Jimmy Carter's election in 1976, in which the governor of Georgia won in every state in the South, even if for slight margins, the South covered in red (the color of the Republicans, to the dismay of the GOP's Brazilian admirers, once they become aware of this fact). 
The South was also the epicenter of the conservative reaction against the advance of secularism in education and customs. Once again, the decisive role was played by the Supreme Court. In 1962, in Engel v. Vitale, the court abolished school-sponsored prayer in public schools. And, in an even more striking ruling, in 1973 the Supreme Court legalized abortion in the first three months of pregnancy, in the landmark case Roe v. Wade. Pushed out of active politics since the setbacks suffered in the beginning of the century with the campaign against the teaching of the theory of evolution in schools and the fiasco of the Prohibition, evangelicals make a comeback in great style, now hand in hand with their centuries-long rivals, the conservative Catholics, and with them strongly contributed to the radical change of the political game in the United States.

\subsection{Polarization and the obscure dimension of sentiment}

Reference to abortion and religious teaching at this point is convenient because it draws attention to a fact often eclipsed, or at least downplayed, in the political science literature on polarization: The psychological predispositions, feelings of empathy and animosity, which are directly correlated with the intensity of conflict. Political Science literature is not entirely ignorant of it, but it lacks the tools to address such dimension. The polarization debate in the United States has been explored mainly by researchers in the field of political psychology.

Before considering this approach, it is worth presenting a summary of the empirical data it highlights.

Ideology is one standard for assessing party polarization. Another is the extent to which partisans treat each other as a stigmatized outgroup. (...) By this standard, there is compelling evidence that voters have become more polarized. Beginning in the mid-1980s, Democrats and Republicans increasingly dislike candidates of the out-party and also hold negative stereotypes of opposing partisans. (...) Affective polarization among ordinary citizens has reached the point where party affiliation is now a litmus test for interpersonal relations. People distance themselves from and are less trusting of partisan opponents. Today, outgroup prejudice based on party identity exceeds the comparable bias based on race, religion, and other significant social cleavages (...) (Iyengar and Krupenkin, 2018).

After four years of crisis and rancorous political clashes, the Brazilian voter understands perfectly the state of affairs the authors of the summary above refer to. The problem is how to proceed from verification of the fact to its analysis. In this regard, the literature discussed thus far, of an eminently rational base, does not take us too far. Construing political conflict as a clash of interests and opinions, colored by the adherence of agents to more or less coherent worldviews, which in relation to the American case is advisable given their self-representation as conservatives or liberals, current approaches in political science find it difficult 
to deal with emotions - an inherent aspect of interindividual relations and collective life.

Moving forward in this territory requires tools from a different toolbox.

Individual identity is built on a dialectic between the "I" and the "we", where the figure of the third person plays a key role. Similarity and difference are the two sides of the same coin. Over and beyond their genetic characteristics, individuals differ from each other for being part of multiple chains of paired opposites. Some of these determinations mark the individual superficially; others define who the individual is - in the individual's own eyes and in the view of others - as a member of this or that collective. It comes as no surprise, therefore, that the tension between "us" and "them", which is relevant in shaping the individual's identity, should awaken visceral reactions in an individual when it becomes critical.

Along with the current studies of polarization in American society, a Political Psychology line has been gaining momentum over the last years that is seeking the tools to move forward in the terrain elliptically alluded to in the preceding paragraph.

This approach explores the importance of partisan links in the identity of somewhat significant swaths of the population and accentuates the difference in treatment that necessarily accompanies the dividing line between social groups.

The human inclination is to prefer and privilege members of the ingroup. The primary result of group membership is simply to hold positive feelings for the ingroup, and no positive feelings toward outsiders. Even this difference can cause discrimination, but is not distinctly hostile. Under circumstances of perceived threat or competition, however, the preference for the ingroup can lead to outright hostility toward the outgroup, particularly when the competition is a zero-sum game (Mason, 2018, p. 12).

The proposition was made by the author of a book programmatically situated at the intersection between Political Science and Political Psychology. Though going over her thought here would be out of place, I wish to draw attention to two interconnected aspects of her thesis in order to introduce the general remark that will serve as my conclusion for this part.

The first one is her insistence on group identity - in the case of political parties - as an autonomous factor in perpetuating conflict, regardless of the interests at stake.

Democrats and Republicans compete for the power to implement very different policy platforms, affecting the entire nation. (...) However, (...) though the parties are competing for real interests, they are also competing because it just feels good 
to win. Distinguishing between those motivations is not a simple matter, but it is important to remember that both motivations are separately present in any political competition (Mason, 2018, p. 47-48).

The second concerns the potentializing effect of superimposed identities. This is a variant of the classic hypothesis of the importance of cross pressures as a mechanism for attenuating conflict. Individuals have multiple identities - or multidimensional identities if you will. In this sense, they participate in several groups simultaneously. Now, if these identities converge, the individual becomes a member of the group - large, engaging, and undifferentiated. This outcome is presented by the author in the following terms:

when multiple identities are strongly aligned, a threat to one identity affects the status of multiple other identities. (...) While stronger identities motivate increased anger and excitement in the face of group threat, more sorted identities have an even larger effect. We have more self-esteem real estate to protect as our identities are linked together (Mason, 2018, p. 85).

Everyone agrees that sorting is the formation of collectivities with a propensity to exhibit the following features: Their members share partisan identities and recognize their affinities as respects ideological orientations and other social attributes. It is no surprise that they respond to their party's political propaganda calls when the party seeks to stigmatize personalities and groups from the opposite camp and to feed adversarial feelings against them.

\subsection{Polarization as effect and strategic goal}

Separate consideration of this approach, which is rooted in another disciplinary area, is opportune, because it further strengthens the two comments that I will make with respect to the literature reviewed.

The first one is focused on its heavy silence regarding a key aspect of political relations in the United States over the last decades. I am talking about the sharp asymmetry between the Democratic Party and the Republican Party. The literature studies the phenomenon of polarization. Occasionally, it states that it is more pronounced in the Republican rank and file, that is, that Republican lawmakers distance themselves from the center in much greater proportion than their Democratic peers. But the literature does not go much further.

Now, there is no symmetry between these two parties, which are in stark contrast in terms of their internal structuring, their relationship with society, their goals, and the ideas that rally their activists and color their internal dissensions. ${ }^{9}$ As noted, with great propriety, by Hacker and Pierson (2005, p. 6):

9. On the constituent differences between the Democratic Party and the Republican Party, see Grossmann and Hopkins (2016). 
polarization is a major and growing problem. But the problem is not just polarization. It is unequal polarization - unequal between Democrats and Republicans, unequal in its effects on the governing aims of liberals and conservatives, and unequal in its effects on American society.

One cannot fully understand the polarization process without considering what the two parties do as respects the way they are organized and the politics they champion. But not only these aspects. It is also worth considering the way they work with conflict, how they define their strategic goals, and how they conduct their tactical activities.

In this regard, it is worth considering the research program developed by Sean Theriault, a University of Texas distinguished teaching professor. I will not comment on any of his works here, but I must underscore the guiding idea that has driven them: The notion of "partisan warfare", or "political warfare", as he later came to prefer (Theriault, 2008; 2013; 2015, p. 11-15).

The reference above brings me to the second general comment on the literature discussed in this topic. Irrespective of all their differences, the approaches considered have so far addressed polarization as the effect of diverse combinations of different causal factors. Yet, with some rare exceptions, they altogether ignore a crucial aspect of the problem: Polarization as an end, as an outcome sought in the context of strategically planned action.

The politics of polarization. It is to that aspect that I shall turn to now.

\section{THE CONSERVATIVE MOVEMENT, THE REPUBLICAN PARTY, AND THE TRUMP CASE}

\subsection{The problem better defined}

With the elements presented so far, we may take the problem referred to in the beginning of this article head on: How should we understand the transformation of Trump - a media and worldly celebrity - into president of the United States?

I found an elaborate answer to this question in a thought-provoking essay by Paul Pierson. His work is much broader, as it includes a strong argument on the discontinuity between the Trump administration's rhetoric and its actual policies. But the first part of his analysis is focused precisely on the subject of my inquiry. As a preliminary to the discussion I will conduct here, it is worth examining the way the problem is approached in his article (Pierson, 2017).

Pierson (2017) begins by saying that, apart from being a stranger to the Republican base, Trump had no previous governmental experience at all and was elected with a platform that departed sharply from his party's orthodoxy. 
This fact cannot be accounted for so much in terms of the support he galvanized in society, but for some salient features of the institutional and political context. In developing such thesis, Pierson (2017) combines nearly all the elements reviewed in the literature and explains the behavior of the voters who voted for Trump on the basis of their aggregate result: The prevalence of "negative voting".

A considerable share of the Republican electorate - about a quarter in the months prior to the election - considered him unqualified to be president, yet 90 per cent of Republican identifiers voted for Trump. At the end of the day, they cast their votes against Hillary Clinton and the Democrats (Pierson, 2017, p. 109).

This, however, is the easiest part of the problem. An explanation was still missing of how and why the Republican Party was prompted to offer to its captive electorate the exotic figure of the New York businessman.

As is known, he was not the preferred option in the leadership circles, far from that. Yet the GOP leadership had good reasons to fear for the result of a dissident candidacy - and Trump made a point of announcing he would take that course should his bid be rejected. Trump's blackmailing power, thus. Not just any reason.

But this was not the main factor at all. The most important factor in Trump's triumphal march was the strategic calculation prevailing in the vast and powerful social network that underpinned the Republican Party, at the center of which was a circle of ultraconservative billionaires and the political/ideological organizations they funded. Equipped with material and intellectual resources to see their long-term interests prevail, these actors were fully aware of the systemic limits of the power of the presidency. To many of them, Trump's rhetoric - support of social programs, broad infrastructure investment program, indiscriminate attacks against immigrants, denunciations against free trade agreements - was despicable. Yet they trusted that, in the end, in the design of a Trump government, their interests would prevail.

This strategic calculation, which sounds all too familiar to Brazilians, was expressed by Grover Norquist, one of the protagonists of the American conservative movement in this century, long before Trump's candidacy appeared on the horizon.

We don't need a president to tell us in what direction to go. We know what direction to go. (...) We just need a president to sign this stuff. We don't need someone to think it up or design it. (...) This is a change for Republicans: The House and Senate doing the work with the president signing bills. His job is to be captain of the team, to sign the legislation that has already been prepared. ${ }^{10}$

10. Available in: <https://www.c-span.org/video/?304376-9/grover-norquist-remarks>. 
By examining the content of Trump's policies, Pierson's article seems to corroborate the correctness of this calculation. I am not so convinced of that, but I will not engage in this debate. What interests me in his argument is his silence regarding Trump's out-of-the-ordinary favoritism, as he appeared far ahead of his contenders in mid-2015, long before the beginning of the primaries season, and never had his favoritism seriously threatened. How can we understand the preference of the Republican base for a character who was a stranger to the party, held positions diametrically opposed to those advocated by his party, and who on top of that exhibited in his curriculum an affiliation, in the recent past, with the opposing party? ${ }^{11}$

To further one's understanding of this anomaly, we must take into account at least three intertwined historical developments: The full constitution of the American conservative movement in the 1950s and its complex relations with the Republican Party; the sweeping transformation of the mass media system in the United States; and the entrenchment in the complex conservative movement/Republican Party of the concept of warfare as the guiding principle of political action. It would not be possible to examine the three of them in this chapter, but I should say a quick word about each one before proceeding to the analysis of Trump's ascent immediate conditioning factors.

\subsection{The conservative movement}

Rooted in the mobilizations against the New Deal's economic and social policies and the involvement of the United States in the war, the main slogan of the protofascist movement America First, founded in 1941 with the decisive support of super-rich businessmen who would later be recognized for their role in the history of the right in the United States and the world, modern American conservatism gains distinctive features in the middle of the last century through the tireless work of a handful of hard-working and creative ideologues.

Hostile to the federal government's regulation of economic activities and social relations, virulently anticommunists, these militant intellectuals were further strengthened in their campaign against the dominant liberal ideas by McCarthyism. In effect, under the dual impact of the loss of nuclear monopoly and the Chinese communist revolution, the liberal establishment went into the 1950s hounded by the anticommunist crusade led by Senator Joseph McCarthy. Entrenched in the House Un-American Activities Committee, McCarthy strived to ferret out the enemy within the government, particularly in the State

11. Trump is the perfect counterexample of the "active voter" type described in the literature. Registering as a Republican in 1987, he changed his affiliation to the Independence Party in 1999, only to declare himself, two years later, a Democrat, remaining as such until 2009, when he returned to the Republican Party. Two years later he declares himself independent to, once again, register as Republican in 2012 (Chasmar, 2015). 
Department. In face of the reactions his methods caused, the leaders of the emerging conservative movement promptly came out in his defense, and two of the most important of them - William F. Buckley Jr. and his cousin Joseph Bozell - came to write a book extolling the senator, who shortly after that would be condemned to ostracism. ${ }^{12}$

The reference to McCarthy is relevant not only because of the importance his crusade had as catalyst for conservative influence, but also because it defines with precision the relationship this movement would establish from its inception with the Republican Party. Expression and privileged channel of the political system's conservatism, the Republican Party had never been seen by the intellectual leaders of the conservative movement as worthy of acritical adherence. On the contrary, since 1952 they had fiercely opposed president Eisenhower, whom they viewed as the executor of Roosevelt's will, and felt betrayed in 1960, when vice-president Richard Nixon sought the support of Nelson Rockefeller, whom they hated, in his first attempt to win the presidential office. To the conservatives in that and in future moments, the dissidence alternative, with the founding of their own party, was always a hypothesis worth considering. If abandoned in favor of their strategy to remain and control the party, that was the result of political calculation. ${ }^{13}$

In order to transform a heteroclitic set of feelings and ideas into a cohesive movement and advance their ultimate goals, the conservatives had to solve the difficult problem of how to fuse into a resistant alloy cultural conservatism - of a religious foundation and with an organicist view of society - and market-driven liberalism and its celebration of individualism. The search for the formula that would allow such alchemy is the intellectual side of conservatism, achieved with the coinage of the phrase "ordered liberty" - a cornerstone principle of what came to be known as "fusionism". ${ }^{14}$

Yet this positive side of the answer was countered by the establishment of borders separating the movement being created from ideological expressions that were close to it but, given their fierce radicalism, could damage the movement's respectability. In this category are the white supremacist groups, often anti-Semitic, and the supporters of more delusional conspiracy theories.

12. The message in the book is eloquently expressed in its last paragraph. "We do not, therefore, intend to get rid of McCarthy. We believe that on McCarthyism hang the hopes of America for effective resistance to Communist infiltration. And if and when McCarthy broadens out, and there have been indications that he will, his spirit may infuse American foreign policy with the sinews and purpose to crush the Communist conspiracy. Only then can we afford to do without McCarthy" (Buckley Jr. and Bozell Jr., 1954, p. 340).

13. For a detailed reconstitution of this clash as experienced by his opponents, see Kabaservice (2012).

14. For more details, see Nash (1996), a classic study by a talented historian who was also an activist. For a more critical perspective, see Himmelstein (1990) and Lowi (1995). 
In this sense, the exclusion of the John Birch Society (JBS), an organization founded in 1958 by businessman Robert Welch, is emblematic. Despite the many and deep affinities, the lunacy of the creator of JBS, who came to include in his list of infiltrated communist agents the likes of Eisenhower, the brothers Allen and Foster Dulles, Judge Earl Warren, and General George Marshall, forced the conservative command to take the decision of drawing a line. This took place in the early 1960s, when the conservatives were getting ready to run for the Republican presidential nomination behind Goldwater. The tool leveraged to such end was the National Review, the movement's magazine, on whose pages William F. Buckley, its founder, lay bare and ridiculed the twisted logic of his troublesome former friend. ${ }^{15}$

This leads us to the other decisive aspect of the conservative ideologues' action. It is Marx's the irreproachable formula according to which ideas when incorporated by the masses turn into material forces. Yet the opposite is also true: Without the "material" tools for their dissemination, the incorporation of ideas by the masses remains indefinitely a mirage.

The conservative intelligentsia did not need to read Marx to convince themselves of that. So, as they sought the solutions to their conceptual conundrums, they were also creating the communication and organizational means required to carry their message to targeted audiences.

That was how they promoted the creation of youth organizations such as the Young Americans for Freedom (YAF), an organization founded in September 1960, at the end of a meeting held at William F. Buckley's home in Sharon, Connecticut. In 1964, the YAF, not alone in the field, proudly announced it had 350 organized groups and 30,000 members spread all over the country.

That was also why these intellectuals had endeavored from the beginning of the previous decade to create a complex network of publishing companies, magazines, and radio and TV programs capable of spreading their word all over the nation.

In 1964, the year the conservative movement debuted on the big politics stage with Barry Goldwater's Republican candidacy, journalist Fred Cook produced a long report on the presence of the conservative right in the radio and TV system. The author of the book that I draw on in this part summarized like this her findings:

charting nine programs, Cook counted 6,600 broadcasts a week, airing on 1,300 stations - about 20 percent of the nation's radio and television outlets - spread over

15. Forty-six years later, Buckley would recount the backstage of that decision, which had the participation of Goldwater himself, in the article available in: <https://www.commentarymagazine.com/articles/goldwater-the-johnbirch-society-and-me/s. 
49 states. (...) An accompanying map of the United States that marked these outlets was so cluttered with spots that Cook remarked it looked "as if the nation were seized with virulent pox" (Hemmer, 2016, p. 110).

This huge system boosted Goldwater's nomination campaign and subsequently his presidential campaign as Republican candidate. The result was an electoral disaster, as is known, yet the political balance for the conservative movement could not have been more positive, as it secured solid platforms from where to launch attacks against GOP "moderates" in the "prolonged war" they waged for control of the Republican Party.

Fifteen years on, Ronald Reagan won.

\subsection{Structural change in the political communication system}

The communication infrastructure developed in the 1950s played a decisive role in that war, but the conservatives resented the restrictions the legislation in place imposed on its use. To be sure, since 1927, when the Radio Act was passed establishing that radio stations had to offer equal opportunity to candidates presenting their viewpoints, TV and radio programming in the United States was regulated by the Federal Communications Commission (FCC) - in line with its normative framework, the Fairness Doctrine. In one word, this doctrine was based on the concept of the public function of broadcasting, namely that of preparing citizens for democratic coexistence, from which derived the ideal of objective journalism and the justification for disciplinary provisions against abuse, dissemination of fake news, and slander against political adversaries.

Conservative ideologues had always challenged this legal framework as against press freedom, an abominable attempt by the State to control people's thought. To them, information was an intangible good of a private nature that should be produced in free-market conditions under the principle of consumer sovereignty.

Their struggle against regulation of broadcasting and the Fairness Doctrine lasted several decades. During this long struggle, many argumentative resources were produced that were widely used in other national contexts, and many modifications were introduced in the regulatory framework. Still, these were marginal changes. The big change came in 1987, when the FCC unanimously revoked the Fairness Doctrine on consideration that it violated freedom of expression, disrespected the Constitution, and was contrary to public interest (Hershey, 1987). ${ }^{16}$

Not by coincidence, at the same time a phenomenon that greatly impacted American political life emerged: The talk shows, radio programs (televised, too,

16. For an analysis of the ups and downs in the struggle against the Fairness Doctrine, see Hemmer (2016, p. 115-125; 258-261). 
though to a smaller extent) whose hosts were most often right leaning and who commented on the most varied political and social issues without any dissenting views and in an overtly partisan fashion. This network's scope and high level of concentration is well expressed in the excerpt below:

regulatory changes allowed Murdock to expand his media holdings (laying the groundwork not only for Fox News but the 2007 acquisition of the Wall Street Journal) and enabled the rise of Clear Channel Communications. By 2000, Clear Channel owned one in every ten radio stations in the United States. Clear Channel and its subsidiary Jacor, in addition to profoundly restructuring the music industry, were the driving forces behind the conservative talk channels that soon saturated the nation (Hemmer, 2016, p. 266-267).

Though dominant, Murdock's empire was not alone. The information that follows describes a picture of right-wing hegemony in this critical industry.

A 2007 study of 257 news/talk stations by the progressive Center for American Progress found 91 percent of the programming was conservative, an imbalance they concluded was not market driven but a result of "multiple structural problems in the U.S. regulatory system (Hemmer, 2016, p. 267).

As the reference to Fox News insinuated, the effect of these regulatory changes were combined with the enormous impact of the technological innovations that were transforming the communication industry's cornerstones over the same period - a process whose initial expression was the advent of cable television, followed by the internet boom in the 1990s, and which today manifests itself in the form of social media. There is an immense bibliography on this process, which all of us have observed as more or less actively engaged participants. I need not dwell on it. Yet I must draw attention to one of its implications, one of crucial importance for the subject of this article. The reader must surely have figured it out. I speak of the fragmentation of the audience: The formation of somewhat closed circuits that broadcast information and comments targeting a specific consumer who shares them in the company of like-minded audience members "people like us" - and passes them on. We refer to them as "bubbles", yet the term widely used today in the United States - echo chambers - is more suggestive.

The impact of this structural change on the polarization process has been researched by Political Science (Levendusky, 2013). Equally studied has been its influence on the unsettling degradation of public debate in the United States, with the overwhelming propagation of bigoted forms of speech (Berry and Sobieraj, 2016).

Furthermore, it is worth noting that, in this realm, relations are also asymmetrical. Though the formation of echo chambers is widespread, taking place along the entire political spectrum, the nature of the communication in each of 
them varies, as are also varied their effects on the political system generally. This is the thesis sustained in a thought-provoking, methodologically rigorous study by three specialists in political communication research who describe their findings in these terms,

the consistent pattern that emerges from our data is that ... there is no left-right division, but rather a division between the right and the rest of the media ecosystem. The right wing of the media ecosystem behaves precisely as the echo-chamber models predict - exhibiting high insularity, susceptibility to information cascades, rumor and conspiracy theory, and drift toward more extreme versions of itself. The rest of the media ecosystem, however, operates as an interconnected network anchored by organizations, both for profit and nonprofit, that adhere to professional journalistic norms (Benkler, Faris and Roberts, 2018, p. 73).

The communication system's structural change had yet another effect of great relevance for our theme. In the past, the barriers to entry into the editorial and broadcasting industries were high, thus facilitating the work of the "border guards" who protected the ideological integrity of the conservative movement, administering tolerance to divergence closely. Once the movable line of what was politically acceptable was crossed, transgressors were punished with exclusion from the organization in which they operated, thus forcing them to withdraw from journalistic activity or accept a job in less prestigious publications. With the advance of the internet this picture changed radically. The cost of entry in the political opinion market fell sharply, enabling the mushrooming of blogs and sites that started to compete for the favor of audiences by offering them ever stronger dosages of the toxic product required.

From regulated market to free zone. The unanticipated outcome of this change was described by Charles J. Sykes, a conservative talk show host and a friend of the movement's guru, William F. Buckley, in these terms:

what we learned was that the walls are down, the gatekeepers dismissed, the norms and standards of journalism and fact-based discourse trashed. In the alternative reality bubble of the conservative media, fake news (...) could spread like a noxious weed. But then again, so could Breitbart News, Alex Jones, and Sean Hannity and their legions of internet trolls who found out they could drive the political narrative, regardless of the fact-checkers or other recognizable measures of reality (Sykes, 2017, p. 91).

Once again, any similarity with what we are witnessing in Brazil is not just a coincidence.

\subsection{Politics conceived of as war}

Clausewitz defined war as the continuation of politics by other means. A strong trend in this period of exacerbated interparty conflict in the United States is the 
consciously produced inversion of the terms of the formula to enable it to be read as war as the truth of politics.

David Horowitz, a former 1960's Marxian and leftist intellectual exponent who eventually converted to right-wing extremism, lay bare the rationale of such operation by discussing the six principles of the "art of political war" in a book widely consumed here in Brazil before Brazilians plunged headlong in the business of regime destabilization we are still in. It is worth taking note of the list:

1) Politics is war conducted by other means.

2) Politics is war of position.

3) In political warfare, the aggressor usually prevails.

4) Position is defended by fear and hope.

5) The weapons of politics are symbols evoking fear and hope.

6) Victory lies on the side of the people.

According to the author in his introduction, the paper from which it borrowed the title was originally published as a pamphlet with the approval of the Republican National Committee and of 34 GOP state committee chairs. It cannot be inferred from that if it was of much influence, but it is possible to see that the favorable reception the text was met with had stemmed from a strong convergence between the ideas it championed and the orientation adopted by Republican politics since the so-called Gingrich Revolution, which enabled the Republican Party to win both houses of the American congress in the November 1994 midterm elections.

The best-known part of the Gingrich strategy was the well-succeeded attempt to nationalize Congress elections through the Contract with America - a list of 10 bills, hand-picked from opinion polls, that the Republicans vowed to pass in 100 days should they win a majority in the House of Representatives.

But this was just the most visible side of the strategy. The other side was a concerted effort to unify the language of GOP candidates by producing a handbook that didactically provided the words that were to be used to stigmatize opponents and praise the qualities of the Republicans' own proposals. That material was spread in tapes all over the country, with generous amounts being invested in training courses on this coded language. ${ }^{17}$ 
Now, these and other initiatives only make full sense when they become part of a plan, thus described by an investigative journalist who had thoroughly studied Gingrich's politics:

Gingrich had a plan. The way he saw it, Republicans would never be able to take back the House as long as they kept compromising with the Democrats out of some high-minded civic desire to keep congressional business humming along. His strategy was to blow up the bipartisan coalitions that were essential to legislating, and then seize on the resulting dysfunction to wage a populist crusade against the institution of Congress itself (Coppins, 2018).

The goal was to reframe the boring policy debates in Washington as a national battle between good and evil, white hats versus black - a fight for the very soul of America (Coppins, 2018).

A professor of history with a strong interest in military history, Gingrich used to define himself as a partisan - an irregular combatant in an undeclared war. This self-image befits the characterization made by McKay Coppins of Gingrich's career.

During his two decades in Congress, he pioneered a style of partisan combat replete with name-calling, conspiracy theories, and strategic obstructionism - that poisoned America's political culture and plunged Washington into permanent dysfunction. Gingrich's career can perhaps be best understood as a grand exercise in devolution - an effort to strip American politics of the civilizing traits it had developed over time and return it to its most primal essence (Coppins, 2018).

Like several other analysts, the author of the excerpt quoted above sees a clear line of continuity between the kind of politics launched by Gingrich and the pattern exhibited by Donald Trump. Though the affinities are very strong, it would be misguided to take them as the key to explaining the phenomenon as manifested in the present, twenty years after the experience that would inaugurate it. In order to understand Trump's trajectory in American politics, we should also consider the very special context the United States was in in the late 2010's.

\section{END OF CYCLE: FINANCIAL CRISIS AND THE UPRISING OF THE REPUBLICAN BASES}

More than ten years on, it is still very difficult to fully grasp the shock caused by the Federal Reserve's decision to deny support to one of the largest and most traditional investment banks in the country, even knowing that by doing so the bank would fail. The decision drew harsh criticisms, yet these were quickly stifled by the avalanche of bad news that followed. To be true, the collapse of Lehman Brothers triggered a chain reaction that in a few days brought about a string of bankruptcies and turned the crisis of the American mortgage market into a global financial crisis - the most severe of all crises of international capitalism since the 1930s. 
The details of this process, its drivers, and economic implications do not interest us here. For the problem at hand what matters, firstly, is the economic authorities' response to the crisis and the way it was perceived.

The facts surrounding those events are well known. Astonished at the Dantean effects of their measure, the Treasury and the Fed organized overnight a bailout operation and imposed its acceptance even on those stronger and/or more prudent banks that, amid the turmoil, felt relatively safe. Meanwhile, Congress voted an emergency relief bill that the GOP ranted against and defeated in the first vote - causing a one-trillion-dollar panic at the New York Stock Exchange (NYSE). When the bill finally passed with bipartisan support from Barack Obama and John McCain, his opponent in the presidential race, the Troubled Asset Relief Program (TARP) authorized the Treasury to spend the astronomical figure of $\$ 700$ billion. Of this amount, $\$ 17.5$ billion were used by the Bush administration to bail out Ford and General Motors, unable to overcome by themselves the financial troubles they were mired in.

The revolt began then. What outraged Republican lawmakers and the GOP rank and file was George Bush's decision to squander public money to bail out some irresponsible banks and their multimillionaire executives, while the wealth of the middle class melted away as the housing market came to a standstill and stocks plummeted.

Actually, the schism between Bush and the conservative movement, which by then had surrendered to the bombastic rhetoric of the talk show stars - were plain to see before that in the criticism of the gigantic fiscal deficits the government was running at that time and of the federal immigration policy.

But the U-turn made during the crisis consummated the divorce. Faced with the contradiction between doctrinaire precepts and the government's actual actions, conservative movement activists, educated for decades in the Manicheism of opposing the good to the bad, rather than calling their doctrine into question, clamored against the politicians that had betrayed it.

Obama's election and the deepening of state intervention policies to dampen the effects of the crisis further disconcerted those groups, who saw in the phlegmatic figure of that dark-skinned, smooth-talking intellectual the materialization of their worst nightmares.

Their reaction was loud and prompt. Catching in the air the idea launched by CNBC reporter Rick Santelli on February 19, 2009, seasoned activists took to the social media to spread the rallying cry "I want my country back!" nationwide, which summed up their diffuse sentiment of outrage. Protests began the same month, gathering a few people in a handful of cities. Yet by early April hundreds 
of thousands rallied on "Tax Day" in cities across the country to express their anger. The Tea Party was born that day (Skocpol and Williamson, 2012, p. 7-8).

From then on, with no central organization or nationally recognized leader, it grew rapidly, coming to bring together 350,000 members and more than 3 million supporters, i.e., individuals who had attended Tea Party rallies and either contributed with the movement financially or acquired its publications (Parker and Barreto, 2013, p. 13).

Evoking an inaugural episode of the American revolution, the Tea Party movement combined, from its inception, the spontaneous impulse of American society's most conservative sectors with the calculated action of strategic actors: The right-wing media, most notably Fox News; billionaire families, and the network of institutions they sponsored - special reference must be made here to the Koch brothers; and right-wing political organizers with a long track record.

A worldwide media phenomenon, the Tea Party movement, was also the subject of quality academic research. I am not able to comment on it here, but I should telegraphically point out some of the movement's traits the research reveals: i) the social profile of its activists - mostly white, religious men, of relatively advanced age, with an income above national average; ii) the discrepancy between the anti-State formal rhetoric of Tea Party representatives and the importance given to other issues, like the toughening of immigration policies; iii) the intense rejection prompted by Barak Obama, expressed in Tea-Partier speech in clearly xenophobic and racist connotations (spreading the myths that Obama was not a native American and a Christian, but a Muslim); iv) the radical rhetoric that has long characterized Republicans, as we have seen, but now targeting not only Democratic adversaries, but also the traitors in control of the Republican party. ${ }^{18}$

This is a crucial point. Though also including Democratic and independent constituents, the Tea Party movement established itself as a movement that challenged the Republican Party from within. This is made evident in the way its members questioned the behavior of GOP leaders and, most importantly, in the strategy adopted to remove from Congress some of the GOP's most important politicians, those they regarded as RINOs (Republicans In Name Only), by defeating them in party nomination processes.

The show of strength of the Tea Party came with the 2010 midterm elections, when the Republican Party won by a landslide, regaining control of the House (winning more than 63 seats, the most seats won in a midterm election since 1938); significantly reducing the Democratic majority in the Senate, and

18. Based on these and other elements, Parker and Barreto (2013) contend that the Tea Party should not be construed as a conservative movement but, rather, as a reactionary movement in the United States far-right's long history. 
advancing at the subnational level, winning a majority in 26 legislatures in addition to 29 state governments. The Tea Party contributed strongly to that result by endorsing the list of Republican candidacies, but most importantly, by setting the agenda of the electoral debate. ${ }^{19}$

For the argument developed herein, however, the most salient feature of the 2010 elections was the fact that the candidates backed by the Tea Party won party primaries challenging mainstream GOP politicians who relied on the strong support of the Republican establishment.

A highly symbolic example of this shift was Marco Rubio's victory against Charlie Crist, the governor of Florida, in the senatorial race. ${ }^{20}$ That was not an isolated case. In 2012 it would be replicated in the race between Ted Cruz, backed by the movement, and David Dewhurst, vice-governor of Texas, also for a seat in the Senate. And two years later in the defeat of House Republican leader Eric Cantor, in the primary in his district in Virginia, running against an unknown economics professor and Tea Party activist.

By then, the presidential campaigns had already been launched, and Trump was ahead of the pack. To be sure, his candidacy had long been under consideration, and was made official in June 2015. At that moment, Trump already appeared as the frontrunner in primary polls, but his nomination approval rating would leap among Republican voters from $20 \%$ to $52 \%$ in the following month (Libby, 2017, p. 19).

As one might assume, Tea Party support to the Trump campaign is to be credited to Trump's spectacular ratings, which resulted mostly from a combination of the movement's practical ideology and the candidate's speech. As noted by the authors of a meticulous study focused on the behavior of the Tea Party in the House:

both groups were ardently anti-Obama. Both were racially resentful. Both favored immigration restrictions, Second Amendment rights, and budgets cuts. Trump, like the Tea Party legislators, consistently invoked a hopeless, doom-and-gloom attitude regarding the current political state of affairs. And (...) both activated largely latent white, working-class, non-college-educated whites (Gervais and Morris, 2018).

Gervais and Morris (2018) argue that a key element in bringing together the Tea Party and Trump was his perception that, even though the Tea in the

19. American National Election Study 2012 survey, "the Tea Party is the "most politically active segment of the GOP electoral base [2]. They are $57 \%$ of all GOP voters and $64 \%$ of Republican primary voters and $66 \%$ of "opinion leaders [2]." Based upon the survey, Tea Party activists make up over $60 \%$ of Republicans who donated money to the party and its candidates, attended rallies, and worked in campaigns." Available in: <http://www.centerforpolitics.org/crystalball/ articles/not-their-cup-of-tea-the-republican-establishment-versus-the-tea-party/>.

20. Not having a majority in his party, Crist ran for a small party and was defeated in the polls by Marco Rubio by nearly $20 \%$ of the votes. 
movement's name meant Taxed Enough Already, Tea Party supporters had a weak commitment to fiscal conservatism.

Yet there was more than mere ideological alignment in the Tea Party's support for the narcissistic tycoon. This is what Ronald T. Libby shows in an article published in November 2015, therefore before the Republican nomination primaries began.

From the material collected by the author, we can see that Trump started courting the Tea Party several years before his presidential bid, and more importantly, that he leveraged the movement's infrastructure to face opposition to his name coming not only from the GOP leadership, but also from donor networks organized by the Koch brothers and other billionaires.

The Tea Party movement remains Trump's base of support and that has propelled him to the head of the Republican pack in national polls. Since 2011, Trump had continued to address Tea Party groups throughout the country. (...) In addition to giving speeches to Tea Party groups (...), Trump co-opted the leadership of grassroots organizations in order to mobilize Tea Party voters to support his candidacy. Because the Koch brothers blocked any support for Donald Trump's candidacy, Trump outsmarted David Koch by hiring the leadership of their grassroots Americans for Prosperity (AFP) out from under them (Libby, 2015). ${ }^{21}$

With this last piece I finish our jigsaw puzzle. In a highly polarized political environment, the 2008 crisis brought about the emergence of a strong movement that challenged the Republican Party's mainstream. This rebellious impulse, present from the beginning, would gain national momentum in 2016, with the GOP's presidential nomination. Trump defeated his mainstream adversaries because they had all joined the race already beaten. His stronger contestants - Ted Cruz, Ben Carson, and Marco Rubio - had not come from the GOP mainstream, but from the conservative movement, which would eventually join the Trump campaign.

Trump's campaign, however, transcended the Tea Party, as demonstrated by the role played in Trump's political career by the electronic tabloid Breitbart and its editor, Steve Bannon, whom Brazilians now know only too well. In fact, Trump's campaign welcomed and served as estuary for various right-wing groups ranging from paleoconservatives, to ethnic nationalists and white supremacists, to former Ku Klux Klan members and neo-Nazis - who till then had been sidelined by the border guards of conservatism.

Trump's victory is the expression of the political representation crisis of the conservative camp, yet at the same time acts on the conservative movement by changing somewhat radically its priorities and speech. 
In a majestic work, Rogers Smith brings down the myth of the liberal roots of American citizenship. As he shows, in a refined analysis supported by a wealth of data, citizenship in the United States emerges as a composite of, true, a liberal trait, Lockean in nature; a republican trait; and a last but not least important trait of an ethnic-racial and profoundly exclusionary nature (Smith, 1997).

Present in the everyday of social relations, in cultural manifestations, and inf the operational routine of public institutions, this exclusionary component gained strong political momentum in movements arising throughout the history of the United States - nativism in the mid-1900's, against Irish and, to a certain extent, German immigrants; the Ku Klux Klan in its successive incarnations; the anti-Semitic populism of Father Charles Coughlin, in the 1930s; George Wallace's segregationist presidential campaign, in 1964... In different shades, ethnic-racial intolerance has always been a vital element in America's long tradition of right-wing populism. ${ }^{22}$

Since the days of the civil rights, for half a century this element has been trampled on, forced to take refuge in euphemistic and secretly kept forms of expression. With Trump, it reacquires dignity, even if relying on other justifications.

Trump's election marks a shift in the political debate in the United States. And everything seems to signal that this shift will last long - as it is hard to imagine the waters flowing back to the riverbed when the obstacle causing the diversion is removed.

In this sense, it would be no exaggeration to say that Trump is a transformative politician.

The problem for us - who keenly observe from a distance the process in the United States - is that the transformation under way in that country also has transformative effects in Brazil and casts a dark shadow over our country's future.

\section{REFERENCES}

ABRAMOWITZ, A. I. The great alignment: race, party transformation, and the rise of Donald Trump. New Haven; London: Yale University Press, 2018, p. 20.

ANSOLABEHERE, S. et al. The decline of competition in U.S. primary elections, 1908-2004. In: MCDONALD, M. P.; SAMPLES, J. (Ed.). The marketplace of democracy: electoral competition and American politics. Washington: Cato/Brookings, 2006. p. 74-101. 
BENKLER, Y.; FARIS, R.; ROBERTS, H. Network propaganda: manipulation, disinformation, and radicalization in American politics. New York: Oxford University Press, 2018.

BERLET, C.; LYONS, M. N. Right-wing populism in America: too close for comfort. New York: Guilford, 2000.

BERRY, J. M.; SOBIERAJ, S. The outrage industry: political opinion and the new incivility. New York: Oxford University Press, 2016.

BLACK, E.; BLACK, M. Divided America: the ferocious power struggle in American politics. New York: Simon \& Schuster, 2007.

BROWNSTEIN, R. The second civil war: how extreme partisanship has paralyzed Washington and polarized America. New York: Penguin Books, 2008.

BUCKLEY JR., W. F.; BOZELL JR., B. McCarthy and his enemies: the record and its meaning. Chicago: Henry Regnery, 1954.

CHASMAR, J. Donald Trump changed political parties at least five times: report. Washington Times, 16 June 2015.

COPPINS, M. The man who broke politics. The Atlantic, 17 Oct. 2018.

FIORINA, M. P.; ABRAMS, S. J.; POPE, J. Cultural war? The myth of a polarized America. New York: Pearson Longman, 2010.

. Disconnect: the breakdown of representation in American politics. Norman: University of Oklahoma Press, 2011.

GERVAIS, B. T.; MORRIS, I. L. Reactionary republicanism: how the Tea Party in the House paved the way for Trump's victory. New York: Oxford University Press, 2018.

GROSSMANN, M.; HOPKINS, D. A. Asymmetric politics: ideological Republicans and group interest Democrats. New York: Oxford University Press, 2016.

HACKER, J. S.; PIERSON, P. Off center: the Republican revolution and the erosion of American democracy. New Haven; London: Yale University Press, 2005.

HEMMER, N. Messengers of the right: conservative media and the transformation of American politics. Philadelphia: University of Pennsylvania Press, 2016.

HERSHEY JR., R. D. F.C.C. votes down Fairness Doctrine in a 4-0 decision. New York Times, 5 Aug. 1987. 
HIMMELSTEIN, J. L. To the right: the transformation of American conservatism. Berkeley; Los Angeles: University of California Press, 1990.

HOPKINS, D. A. Red fighting blue: how geography and electoral rules polarize American politics. Cambridge, United Kingdom: Cambridge University Press, 2017.

IYENGAR, S.; KRUPENKIN, M. The strengthening of partisan affect. Advances in Political Psychology, v. 39, n. 1, p. 201-218, 2018.

KABASERVICE, G. Rule and ruin: the downfall of moderation and the destruction of the Republican Party, from Eisenhower to the Tea Party. New York: Oxford University Press, 2012.

KAZIN, M. The populist persuasion: an American history. New York: Basic Books, 1995.

KEY, V. O. Southern politics in state and nation. New York: Vintage Books, 1949.

LEVENDUSKY, M. The partisan sort: how liberals became Democrats and conservative became Republicans. Chicago; London: University of Chicago Press, 2009.

How partisan media polarize America. Chicago; London: University of Chicago Press, 2013.

LIBBY, R. T. Has the Tea Party eclipsed the Republican establishment in the 2016 presidential elections? Journal of Political Science and Public Affairs, v. 3, n. 3, p. 1-10, 2015.

Les deplorables: how the Tea Party put Trump into office $\&$ rules America. Saint Augustine: Twelve Tables, 2017.

LOWI, T. J. The end of the Republican era. Norman: University of Oklahoma Press, 1995.

MASON, L. Uncivil agreement: how politics became our identity. Chicago; London: University of Chicago Press, 2018.

MCCARTY, N.; POOLE, K. T. ; ROSENTHAL, H. Polarized America: the dance of ideology and unequal riches. Cambridge, United States; London: MIT, 2006.

NASH, G. H. The conservative intellectual movement in America since 1945. Wilmington: Intercollegiate Studies Institute, 1996.

PARKER, C. S.; BARRETO, M. A. Change they can't believe in: the Tea Party and reactionary politics in America. Princeton: Princeton University Press, 2013. 
PIERSON, P. American hybrid: Donald Trump and the strange merger of populism and plutocracy. The British Journal of Sociology, v. 68, n. S1, p. 106-119, 2017.

SKOCPOL, T.; FINEGOLD, K. State capacity and economic intervention in the early New Deal. Political Science Quarterly, v. 97, n. 2, p. 255-278, 1982.

SKOCPOL, T.; WILLIAMSON, V. The Tea Party and the remaking of Republican conservatism. New York: Oxford University Press, 2012.

SMITH, R. M. Civic ideal: conflicting visions of citizenship in U.S. history. New Haven: Yale University Press, 1997.

SYKES, C. J. How the right lost its mind. New York: St. Martin's, 2017.

THERIAUlT, S. M. Party Polarization in Congress. New York: Cambridge University Press, 2008.

. The gingrich senators: the roots of partisan warfare in Congress. New York: Oxford University Press, 2013.

. Partisan warfare is the problem. In: HOPKINS, D. J.; SIDES, J. (Ed.).

Political Polarization in American Politics. New York: Bloomsbury, 2015. p. 11-15. 